\title{
Water deficit affects photosynthetic induction in Bauhinia forficata Link (Fabaceae) and Esenbeckia leiocarpa Engl. (Rutaceae) growing in understorey and gap conditions
}

\author{
Maria T. Portes ${ }^{1,2}$, Thiago H. Alves ${ }^{2}$ and Gustavo M. Souza ${ }^{1,2 *}$ \\ ${ }^{1}$ Instituto de Biociências, Programa de Pós-graduação em Biologia Vegetal, Universidade Estadual Paulista, 13506-900, Rio Claro, \\ SP, Brasil. ${ }^{2}$ Laboratório de Ecofisiologia Vegetal, Universidade do Oeste Paulista, 19067-175, Presidente Prudente, SP, Brasil. \\ *Corresponding author: gustavo@unoeste.br
}

Received: 17 November 2006; Returned for revision: 24 January 2007; Accepted: 07 March 2007

In tropical forests, light is considered the most limiting resource for plant growth and reproduction. Besides light, water deficit leads invariably to a decrease in photosynthesis. Thus, despite of the unquestionable role of light in $\mathrm{CO}_{2}$ assimilation $(A)$, it is expected that water deficit affects and limits the light utilization by plants. In this study, we investigated how water deficit influenced the photosynthetic induction of the early successional tree Bauhinia forficata (Fabaceae) and the late successional Esenbeckia leiocarpa (Rutaceae) in the understorey and in the forest gap. Field measurements were carried out in June and August 2006 in plants of approximately two-years-old. In August, the plants were subjected to a period of $45 \mathrm{~d}$ without rain characterizing a water deficit situation. Leaf water potential was significantly lower in August, both in forest gap and understorey (-2.5 and -3.8 MPa, respectively), than in June (-0.6 and -1.6 MPa, respectively). In June, both species presented a rapid increase in $A$ after a saturating light pulse under gap conditions. However, in the understorey the increase in $A$ was slower in B. forficata than in E. leiocarpa. In August water deficit limited the increase in $A_{\text {max }}$ in both species, indicating that potential utilization of increasing irradiance was reduced by water deficit conditions. The constrain in $A_{\max }$ was less pronounced in the understorey where plants at least reached the irradiance compensation point, whereas carbon gain by photosynthesis of the plants grown in the gap did not compensate the carbon loss by respiration.

Key words: drought, ecophysiology, gas exchange, light utilization, sunflecks, tropical forest succession

Déficit hídrico afeta a indução fotossintética em Bauhinia forficata Link (Fabaceae) e em Esenbeckia leiocarpa Engl. (Rutaceae) desenvolvendo-se em condições de sub-bosque e de clareira: Em florestas tropicais, a luz é considerada o recurso mais limitante para o crescimento e reprodução das plantas. Além da luz, o déficit hídrico leva invariavelmente à diminuição da fotossíntese. Assim, apesar do indiscutível papel da luz na assimilação de $\mathrm{CO}_{2}(A)$, espera-se que o déficit hídrico afete e limite a utilização da luz pelas plantas. Neste estudo, investigou-se como o déficit hídrico influenciou a indução fotossintética de uma espécie pioneira arbórea, Bauhinia forficata (Fabaceae), e de uma secundária, Esenbeckia leiocarpa (Rutaceae), no sub-bosque e na clareira. As medidas foram feitas em junho e agosto de $2006 \mathrm{em}$ plantas com aproximadamente dois anos. Em agosto, as plantas foram sujeitas a um período de $45 \mathrm{~d}$ sem chuva, caracterizando uma situação de déficit hídrico. O potencial hídrico foliar foi significativamente menor em agosto, na clareira e no sub-bosque (-2,5 e -3,8 MPa, respectivamente), do que em junho (-0,6 and -1,6 MPa, respectivamente). Em junho, ambas espécies apresentaram um rápido aumento em $A$ após o pulso de luz saturante na clareira. Contudo, no sub-bosque, o aumento em $A$ foi mais lento em B. forficata do que em E. leiocarpa. Em agosto, o déficit hídrico limitou o aumento em $A_{\max }$ em ambas espécies, indicando que a utilização potencial do aumento da irradiância foi reduzida por condições de déficit hídrico. A restrição em $A_{\max }$ foi menos pronunciada no sub-bosque, onde as plantas ao menos atingiram a irradiância de compensação, enquanto o ganho de carbono pela fotossíntese das plantas desenvolvidas na clareira não compensou a perda de carbono pela respiração.

Palavras-chave: ecofisiologia, seca, sucessão florestal tropical, "sunflecks", trocas gasosas, utilização da luz 


\section{INTRODUCTION}

Considering all environmental factors affecting plants, light is perhaps the most spatially and temporally heterogeneous. This heterogeneity takes on special importance in tropical forests because light is considered the most limiting resource for plant growth and reproduction. Accordingly, the life cycle and physiological responses of many trees and understorey species have been shown to be closely related to changes in light availability (Bazzaz and Pickett, 1980; Denslow, 1980; Denslow, 1987). Light acclimation is the process that allows environmentally induced changes in the photosynthetic utilization of light, depending upon the light regime under which leaves develop (Björkman, 1981). Comparisons between low- and high-light specialists suggest that these two groups of plant species generally exhibit different capacities for light acclimation (Björkman, 1981; Strauss-Debenedetti and Bazzaz, 1996). Early-successional species generally exhibit a high degree of plasticity in photosynthetic capacity compared to species of later forest successional stages (Strauss-Debenedetti and Bazzaz, 1996). However, both light-demanding and shade-tolerant species are capable of phenotypic plasticity, indicating that adjustments are not necessarily related to the species successional status (Turnbull, 1991; Popma et al., 1992). Phenotypic plasticity may be essential for survival in heterogeneous and variable environments, especially for sessile photosynthetic organisms (Bradshaw, 1965; Sultan, 1992; Pintado et al., 1997).

Changes in the light environment experienced by forest plants during their lifetime may range from sunflecks, lasting from seconds to minutes, to more sustained changes occurring when gaps are formed or canopies develop (Pearcy and Sims, 1994). Sunflecks are generally more limited as a light resource in shade than in sunny microsites in plant canopies, since they contribute with $60-90 \%$ of total daily photosynthetic photon flux density (PPFD) received by plants in the understorey of tropical rain forests, driving up to $65 \%$ of total daily carbon gain (Pearcy, 1983; Pearcy and Calkin, 1983; Chazdon, 1988; Pfitsch and Pearcy, 1989). In this variable and constraining understorey light environment, plants depend on sunflecks to maintain a positive carbon balance (Chazdon, 1988). Sunfleck utilization requires quick activation of the plant's photosynthetic system in order to exploit the brief light pulses. Photosynthetic induction response is dependent on several regulatory mechanisms working at different time scales (Pearcy, 1999). The lightdependent stomatal opening process is relatively slow, whereas light-dependent activation of photosynthetic enzymes and build-up of the Calvin cycle metabolite pool can occur within a few minutes (Edwards and Walker, 1983; Pearcy, 1999). The degree to which a high state of induction can be maintained during variable irradiance partially determines the species capacity to exploit sunflecks within plant canopies (Pearcy, 1990).

In addition to light, water availability is one of the most important constraints for plant productivity, mostly affecting the growth of leaves and roots, stomatal conductance, photosynthesis and dry matter accumulation (Blum, 1997). Water deficit leads invariably to a decrease in photosynthetic rate, although levels of tolerance can vary for different plant species (Kaiser, 1987; Chaves, 1991; Larcher, 1995; Chaves et al., 2002). Stomatal closure influences photosynthesis reduction as a consequence of reduced leaf water potential induced by drought (Chaves 1991; Santos et al., 2004; 2006). Also, a decrease in stomatal conductance is a common response to soil and leaf water limitations (Tardieu and Simonneau, 1998). Thus, despite of the basic and unquestionable role of light in $\mathrm{CO}_{2}$ assimilation, it is expected that water deficit affects and limits the utilization of this resource by plants.

According to the spatial and temporal plant distribution in the forest mosaic, woody species may be broadly classified into two groups: (i) an early successional group with light-demanding species (pioneer and early secondary species); and (ii) a late successional group with shade-tolerant species (late secondary species) (Pickett et al., 1987). Therefore, we hypothesize that late successional species growing in low-light environments, where plants have low carbon gain (Chazdon et al., 1996; Strauss-Debenedetti and Bazzaz 1996), must minimize carbon loss reducing both respiration and tissue construction cost (Givnish, 1988) and maximize light utilization by improving their photosynthetic induction. Furthermore, we expected that, even under water deficit, late successional species would maintain a higher state of photosynthetic induction than pioneer ones, since the latter species 
often show higher transpiratory rates to support high levels of $\mathrm{CO}_{2}$ assimilation (Bazzaz and Pickett, 1980; Souza et al., 2004).

Thus, in order to test these hypotheses, the aim of this study was to investigate water deficit influence on photosynthetic induction in two tree species of different successional groups, growing in the understorey and in the forest gap.

\section{MATERIAL AND METHODS}

Plants characterization and study site: In this study we analyzed plants of approximately two-years-old of different ecological groups, Bauhinia forficata Link (Fabaceae) and Esenbeckia leiocarpa Engl. (Rutaceae). The former species is an early successional and the latter is a late successional species (Lorenzi, 1992). Three saplings of each species were planted directly in the soil in the understorey and forest gap environment, without addition of fertilizers or extra water supply, developing under naturally changing environment.

The gap studied herein presents an area of $34.5 \mathrm{~m}^{2}$, which corresponds to a small gap with canopy openness around $10 \%$ following the classification proposed by Martins and Rodrigues (2002). The study site is situated in a fragment of semi-deciduous seasonal forest with 5.5 ha located in Narandiba (22 24'24' S; 51'31'29' W, 354 a.s.1.), São Paulo State, Brazil. The climate is Aw type, defined as tropical with wet summer, according to the Köppen classification. The region has a mean annual temperature of $23^{\circ} \mathrm{C}$, mean rainfall of $1223 \mathrm{~mm}$ and a mean annual potential evaporative demand of $1170 \mathrm{~mm}$ (Embrapa, 2003). The mean incident daily PPFD, from 0800 to $1600 \mathrm{~h}$, was measured at one hour intervals using a quantum sensor attached to the leaf chamber of the infrared gas analyzer device (CIRAS-2, PPSystems, Hertfordshire, UK) (Figure 1). In the forest gap maximum PPFD was around $1600 \mu \mathrm{mol} \mathrm{m} \mathrm{m}^{-2} \mathrm{~s}^{-1}$ and, in the understorey, it did not exceed $25 \mu \mathrm{mol} \mathrm{m}{ }^{-2} \mathrm{~s}^{-1}$. Air vapor

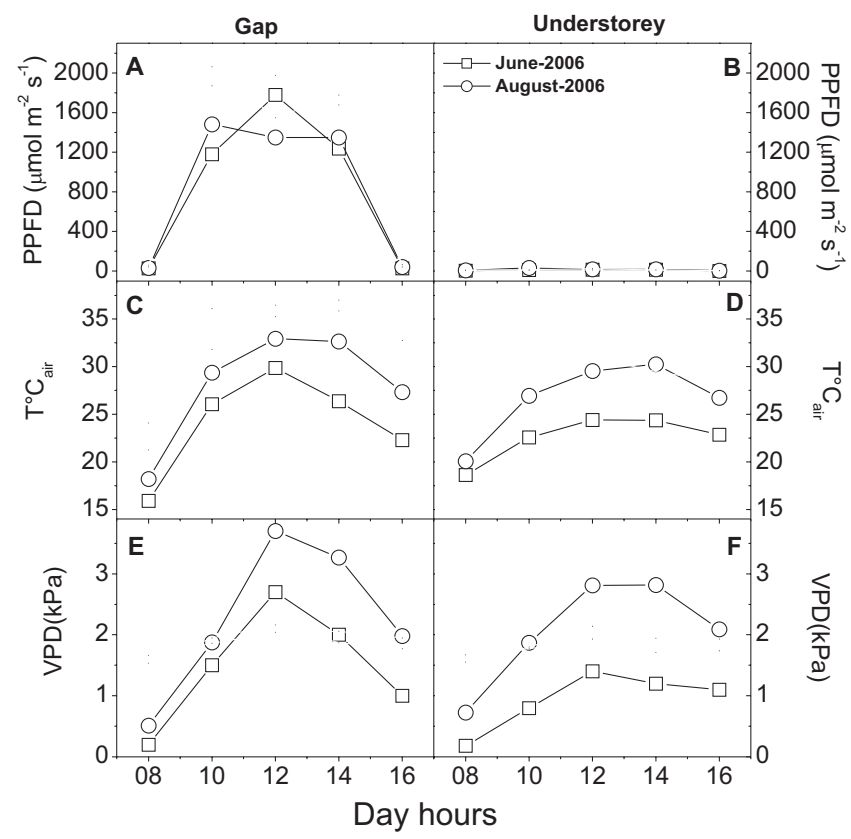

Figure 1. Daily courses of photosynthetic photon flux density (PPFD), air temperature $\left(\mathrm{T}_{\text {air }}\right)$ and vapor pressure deficit (VPD) in the gap (A, C, E) and in the understorey (B, D, F) in June (squares) and August (circles) 2006.

pressure deficit $\left(\mathrm{VPD}_{\text {air }}\right)$ under gap conditions reaches 2.8 and $4.0 \mathrm{kPa}$ in June and August, respectively, whereas in the understorey maximum $\mathrm{VPD}_{\text {air }}$ was $1.5 \mathrm{kPa}$ in June and $2.8 \mathrm{kPa}$ in August. These values were observed around mid-day, when air temperatures were high (Figure 1).

The soil nutrient analysis of the gap and understorey (Table 1) indicates a typical impoverished soil of tropical forest regions (Riddoch et al., 1991). Remarkable differences between gap and understorey environments were not detected. The experiment was carried out without any kind of nutrient supplies as the objective of the study was to simulate natural environmental conditions as closely as possible.

The field measurements were carried out in June and August 2006. Environmental conditions, especially water

Table 1. Soil analysis of nutrients and organic matter (O.M.) in both gap and understorey in August 2006.

\begin{tabular}{|c|c|c|c|c|c|c|c|c|c|c|}
\hline \multirow{2}{*}{ Environment } & \multirow{2}{*}{$\mathrm{pH}$} & $\mathrm{Al}$ & $\mathrm{Ca}$ & $\mathrm{Mg}$ & $\mathrm{K}$ & $\mathrm{P}$ & $\mathrm{S}$ & $\mathrm{Mn}$ & $\mathrm{Fe}$ & \multirow{2}{*}{$\frac{\text { O.M. }}{\left(\mathrm{g} \mathrm{dm}^{-3}\right)}$} \\
\hline & & \multicolumn{5}{|c|}{$\left(\mathrm{mmol}_{\mathrm{c}} \mathrm{dm}^{-3}\right)$} & \multicolumn{3}{|c|}{$\left(\mathrm{mg} \mathrm{dm}^{-3}\right)$} & \\
\hline Gap & 3.8 & 10 & 1 & 1 & 0.3 & 8 & 9.6 & 4.6 & 70.1 & 17 \\
\hline Understorey & 4.0 & 8 & 4 & 2 & 1.1 & 8 & 8.7 & 9.6 & 87.5 & 19 \\
\hline
\end{tabular}




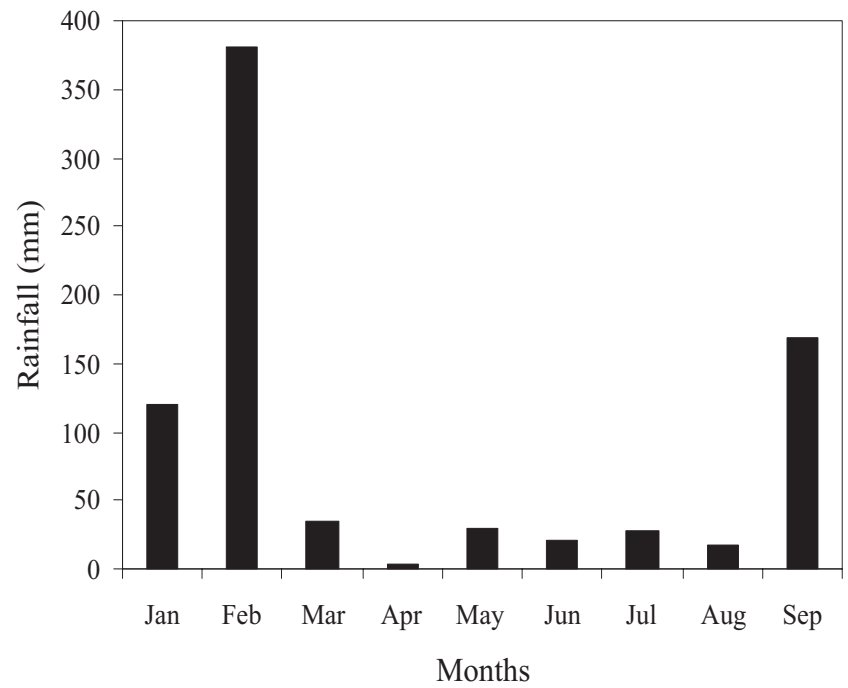

Figure 2. Rainfall of January to September 2006 at the study site, a forest fragment located in Narandiba, southeastern Brazil.

availability, were different in these evaluation dates. Rainfall data obtained from a meteorological station at the study site are presented in Figure 2. Rainfall values were 21 and $18 \mathrm{~mm}$ in June and August, respectively. Despite the small difference between these values, in August the measurements were carried out after a period of $45 \mathrm{~d}$ without rain.

Plant growth was evaluated taking into account primary and secondary growth measured as plant height and stem diameter at $5 \mathrm{~cm}$ height, respectively. In order to determine specific leaf weight (SLW), leaf area was measured with an area meter (Li-3000A, Licor, Nebraska, USA) and leaf dry mass was obtained after drying at $60{ }^{\circ} \mathrm{C}$ until constant weight. Leaf nutrient concentrations (N, P and other elements) were evaluated according to Malavolta et al. (1997). Leaf $N$ content was determined by the Kjeldahl method (i.e., digestion in concentrated sulfuric acid, followed by distillation and titration), and the other elements by atomic absorption spectrophotometry. All measurements were taken in five healthy and fully developed leaves of each species in both light environments in August 2006. The leaves used to these measurements were not necessarily the same leaves used in leaf water potential or photosynthetic induction measurements.

Leaves used for measuring photosynthetic induction responses were darkened for $10 \mathrm{~min}$ inside the sample chamber of the above-mentioned infrared gas analyzer covered with a black cloth, reducing incident irradiance on the sampled leaf to zero (enabling an initial reading of dark respiration). After this period, leaves were exposed to a pulse of saturating PPFD $\left(1000 \mu \mathrm{mol} \mathrm{m} \mathrm{m}^{-2} \mathrm{~s}^{-1}\right)$. The pulse intensity was determined previously by Souza et al. (unpublished data) through light response curves.

Gas exchange measurements: In both environments leaf gas exchange measurements were carried out from 0900 to $1600 \mathrm{~h}$ in healthy and fully developed leaves, from the upper exposed parts of the shoots. Three plants per species (one leaf per plant) were evaluated in each environmental condition. All measurements were recorded on days with no or few clouds. Measurements of net $\mathrm{CO}_{2}$ assimilation $(A)$, stomatal conductance $\left(g_{\mathrm{s}}\right)$, intercellular $\mathrm{CO}_{2}$ concentration $\left(C_{\mathrm{i}}\right)$, and dark respiration $\left(R_{\mathrm{d}}\right)$ were recorded using the CIRAS-2, at $10 \mathrm{~s}$ intervals. Photosynthetic induction state (IS) was calculated as described in Chazdon and Pearcy (1986a), as follows: IS $(\%)=100 \times\left[\left(A_{\text {max }}-A_{\text {low }}\right) \times\left(A-A_{\text {low }}\right)^{-1}\right]$, in which $A$ is the transient $\mathrm{CO}_{2}$ assimilation rate at the time of calculation, $A_{\text {low }}$ is the steady-state assimilation rate in low light and $A_{\max }$ is the steady-state light saturated assimilation rate. Photosynthetic induction curves were fitted using a sigmoidal model following Zipperlen and Press (1997).

Leaf water potential measurements: Leaf water potential $\left(\Psi_{w}\right)$ was measured using a Scholander pressure chamber (model PMS-1000, PMS Instruments, Oregon, USA). The measurements were performed at pre-dawn, before the first sunbeams reached the forest gap.

Data analysis: Differences in mean values of $\Psi_{\mathrm{w}}$, maximum assimilation, $R_{\mathrm{d}}$ and IS between the two species growing in two contrasting forest light environments were analyzed by one-way analysis of variance (ANOVA) and the mean values compared by a posteriori Tukey's test, at 0.05 significance level. Data transformation was unnecessary since they were normally distributed and homoscedastic.

\section{RESULTS}

Leaf $\mathrm{N}$ and $\mathrm{P}$ concentrations did not differ significantly $(P>0.05)$ between the two species, even when comparing gap and understorey environments. 
However, SLW was higher $(P<0.05)$ under gap than understorey conditions for both species. The nonpioneer species E. leiocarpa showed higher SLW in both environments than that of the pioneer one $B$. forficata (Table 2).

Bauhinia forficata was taller and had larger diameter than E. leiocarpa in both environments; the former presented larger height and diameter in the gap than in the understorey (Table 3 ). The differences between environments were smaller in E. leiocarpa for both parameters. Theses results make evident the expected growth differences. The growth parameters analyzed clearly indicate that the pioneer species showed a higher growth compared with the non-pioneer species, especially in the gap (Table 3 ).

In August, when plants were exposed to a long period without rain, $\Psi_{\mathrm{w}}$ was significantly lower $(P<0.05)$ than in June in both forest gap and understorey (Table 4). In the forest gap, $\Psi_{\mathrm{w}}$ was -0.6 and $-2.5 \mathrm{MPa}$ in June and August, respectively. In the understorey $\Psi_{w}$ was considerably lower, -1.6 in June and -3.8 MPa in August. Therefore, the low $\Psi_{w}$ obtained in August characterize a substantial leaf water deficit.

In June, B. forficata and E. leiocarpa presented a rapid increase in $A$ after a saturating light pulse in the forest gap (Figure 3). This result indicates that irradiance activates the photosynthetic apparatus, supporting high photosynthetic induction in these plants (Figure 5). In the understorey, the slower increase in $A$ of $B$. forficata indicates that in shade conditions this species takes more time to fully activate the photosynthetic apparatus. The $A$ reached in the steady-state for $B$. forficata in both environments was very similar. However, E. leiocarpa presented lower $A_{\max }$ in the understorey than in the forest gap. There were no significant differences $(P>0.05)$ between IS reached by E. leiocarpa and B. forficata in both environments. On the other hand, IS was higher in the forest gap than in the understorey for both species (Figure 5).

For both species, $g_{\mathrm{s}}$ was greater in the forest gap than in the understorey (Figure 3 ). In the understorey, as $A$ increased slowly in $B$. forficata an increase in $g_{s}$ and a decrease in $C_{\mathrm{i}}$ occurred. This result indicated that $\mathrm{CO}_{2}$ was consumed to a greater extent when $g_{\mathrm{s}}$ increased, thus supporting the increase in $A$. In both environments, $C_{\mathrm{i}}$ was high before the saturating light pulse, decreasing afterwards (Figure 3 ). In the forest gap, as $A$ increased, $g_{\text {s }}$ and $C_{\mathrm{i}}$ decreased. In the understorey, E. leiocarpa presented low $g_{\mathrm{s}}$ and the increase in $A$, although small, was not accompanied by a decrease in $C_{\mathrm{i}}$, as observed in the forest gap and also in B. forficata. In plants with no limiting $\Psi_{\mathrm{w}}$ (June), the $C_{\mathrm{i}}$ reduction after a saturating light pulse indicates that the carbon had been used in photosynthesis.

The fast response in $A$ of E. leiocarpa in the forest gap, after $10 \mathrm{~min}$ of darkness, indicates the potentiality of this species in readily exploiting irradiance increases. This result indicates that this species is capable of quickly activating its photosynthetic apparatus in order to maximize the utilization of irradiance increases, since it is a late successional species, typical of the understorey.

The highest $A_{\text {max }}$ were observed in June (Figure 5). In both months, we did not observe significant differences $(P>0.05)$ between species in the same environment. In June, E. leiocarpa presented higher $A_{\max }$ in the forest gap than in the understorey, and $B$. forficata did not present significant differences between environments. Despite low $A_{\max }$ under water deficit (August), B. forficata presented higher IS in the forest gap. Nevertheless, $E$. leiocarpa did not present significant differences between environments. High values of IS showed by plants under water deficit (Figure 5) were related to the fact that $A_{\text {max }}$ has been quickly reached (Figure 4). This is due to the calculation of IS, which is based on the relationship between $A_{\max }$, the steady-state light saturated assimilation rate, and $A_{\text {low }}$, the net assimilation rate $60 \mathrm{~s}$ after the saturating light pulse. However, it is important to notice that in both environments $A$ was very low and virtually near to the compensation point. In June, the highest IS was observed in the forest gap for both species (Figure 5).

In August water deficit clearly limited the increase in $A$ after the saturating light pulse, however, there was a slight increase in $A$ in both species and environments (Figure 4). After the saturating light pulse E. leiocarpa, in the gap, presented a decrease in $R_{\mathrm{d}}$ from -4 to close to 0 $\mu \mathrm{mol} \mathrm{CO}_{2} \mathrm{~m}^{-2} \mathrm{~s}^{-1}$, and $B$. forficata from -2.5 to $-0.5 \mu \mathrm{mol}$ $\mathrm{CO}_{2} \mathrm{~m}^{-2} \mathrm{~s}^{-1}$, showing that, although positive values of $A$ have not been reached, a positive response of the photosynthetic activity took place. Under water deficit, both species presented very low $g_{s}$ in the understorey and gap environments. Moreover, after the saturating light pulse there was a decrease in $C_{\mathrm{i}}$ in both species and 
Table 2. Specific leaf weight (SLW), phosphorus (P) and nitrogen (N) concentrations in leaves of B. forficata and E. leiocarpa in both understorey and forest gap. Capital letters indicate significant differences between species in the same environment, and small letters refer to statistical differences between environments in the same species $(P<0.05$, Tukey's test). Data are the mean $(n=5) \pm \mathrm{SE}$.

\begin{tabular}{clccc}
\hline \multirow{2}{*}{ Species } & Environment & \multicolumn{3}{c}{ Parameters } \\
\cline { 3 - 5 } & & SLW $\left(\mathrm{kg} \mathrm{m}^{-2}\right)$ & $\mathrm{P}\left(\mathrm{g} \mathrm{kg}^{-1}\right)$ & $\mathrm{N}\left(\mathrm{g} \mathrm{kg}^{-1}\right)$ \\
\hline Bauhinia forficata & Gap & $1.36 \pm 0.07 \mathrm{Bb}$ & $1.23 \pm 0.18 \mathrm{~ns}$ & $31.87 \pm 1.24 \mathrm{~ns}$ \\
& Understorey & $0.40 \pm 0.06 \mathrm{Ba}$ & $1.70 \pm 0.25 \mathrm{~ns}$ & $32.70 \pm 1.45 \mathrm{~ns}$ \\
Esenbeckia leiocarpa & Gap & $3.28 \pm 0.64 \mathrm{Aa}$ & $2.20 \pm 0.36 \mathrm{~ns}$ & $31.37 \pm 1.45 \mathrm{~ns}$ \\
& Understorey & $1.31 \pm 0.07 \mathrm{Ab}$ & $2.21 \pm 0.10 \mathrm{~ns}$ & $28.47 \pm 1.12 \mathrm{~ns}$ \\
\hline
\end{tabular}

Table 3. Growth parameters, height and diameter, in Bauhinia forficata and Esenbeckia leiocarpa grown in gap and understorey environments. Capital letters indicate significant differences between species in the same environment, and small letters refer to statistical differences between environments in the same species $(P<0.05$, Tukey's test $)$. Data are the mean $(n=5) \pm \mathrm{SE}$.

\begin{tabular}{lccccc}
\hline \multirow{2}{*}{ Species } & \multicolumn{2}{c}{ Height $(\mathrm{cm})$} & & \multicolumn{2}{c}{ Diameter $(\mathrm{mm})$} \\
\cline { 2 - 3 } \cline { 5 - 6 } & Gap & Understorey & & Gap & Understorey \\
\hline Bauhinia forficata & $121.0 \pm 13.7 \mathrm{Aa}$ & $105.5 \pm 0.4 \mathrm{Aa}$ & & $13.8 \pm 0.7 \mathrm{Aa}$ & $9.0 \pm 0.2 \mathrm{Ab}$ \\
Esenbeckia leiocarpa & $64.3 \pm 1.6 \mathrm{Ba}$ & $1.70 \pm 0.25 \mathrm{~ns}$ & & $7.8 \pm 0.4 \mathrm{Ba}$ & $7.5 \pm 0.4 \mathrm{Aa}$ \\
\hline
\end{tabular}

Table 4. Leaf water potential $\left(\Psi_{w}\right)$ of Bauhinia forficata and Esenbeckia leiocarpa in both understorey and forest gap in June and August 2006. Capital letters indicate significant differences between light environments, and small letters refer to statistical differences between months ( $P<0.05$, Tukey's test). Data are the mean $(n=3) \pm \mathrm{SE}$.

\begin{tabular}{clcc}
\hline \multirow{2}{*}{ Species } & \multirow{2}{*}{ Months } & \multicolumn{2}{c}{ Water potential (-MPa) } \\
\cline { 3 - 4 } & & Gap & Understorey \\
\hline Bauhinia forficata & June & $0.55 \pm 0.08 \mathrm{Bb}$ & $1.25 \pm 0.13 \mathrm{Ab}$ \\
& August & $2.47 \pm 0.22 \mathrm{Ba}$ & $3.30 \pm 0.06 \mathrm{Aa}$ \\
Esenbeckia leiocarpa & June & $0.70 \pm 0.11 \mathrm{Bb}$ & $1.75 \pm 0.16 \mathrm{Ab}$ \\
& August & $2.67 \pm 0.12 \mathrm{Ba}$ & $4.17 \pm 0.33 \mathrm{Aa}$ \\
\hline
\end{tabular}

environments, even without a significant increase in $A$.

Dark respiration was higher in the forest gap in both months for both species (Figure 5). Significant differences $(P<0.05)$ between species in the same environment were not found.

\section{DISCUSSION}

Values of leaf $\Psi_{w}$ as measured in August in both environments have been considered very low (Souza et al., 2004), indicating a strong water deficit. Despite the higher evaporative demand in the gap, $\Psi_{w}$ was even lower in the understorey and is probably related to a higher plant covering density (Table 4). Moreover, the leaf transpiration surface and the surface exposed to direct radiation are both much higher in the canopy than in the gap. Although forest gap presents higher temperatures due to higher incident irradiance and more exposed soil, the transpiratory surface in contact with atmosphere is much lower, thus, total evapotranspiration is lower than in the surrounding forest composed by trees with dense canopies with a very high gas-exchange surface (Larcher, 1995). Another factor that decreases water availability to younger plants in the understorey, which have a shallower root system, is the occurrence of tall adult tree species with deep and well-established root system. Thereby, the effects on plant performance under water deficit could be more critical in the shade than in the open. Similar results were reported by Valladares and Pearcy (2002) who attributed the greater soil moisture depletion (dry season) in the understorey to greater competition for water. Similarly, Abrams and Mostoller (1995) found that shaded understorey leaves of all species studied were more susceptible to drought than 

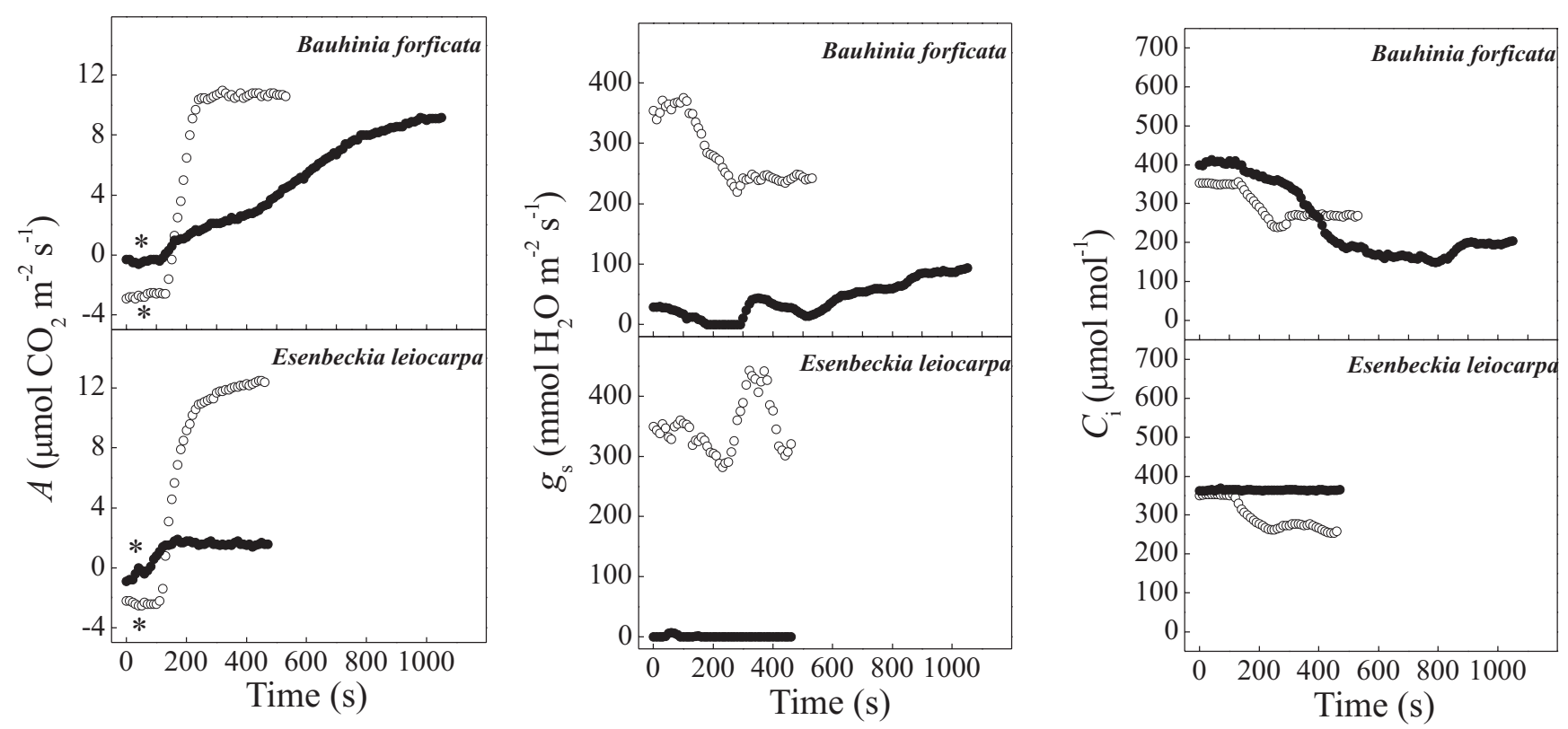

Figure 3. Time course of the net $\mathrm{CO}_{2}$ assimilation rate $(A)$, stomatal conductance $\left(g_{\mathrm{s}}\right)$ and intercellular $\mathrm{CO}_{2}$ concentration $\left(C_{\mathrm{i}}\right)$ in leaves of Bauhinia forficata and Esenbeckia leiocarpa in the understorey (closed symbols) and in the forest gap (open symbols) in June. Asterisks indicate the saturating light pulse after $10 \mathrm{~min}$ of darkness.
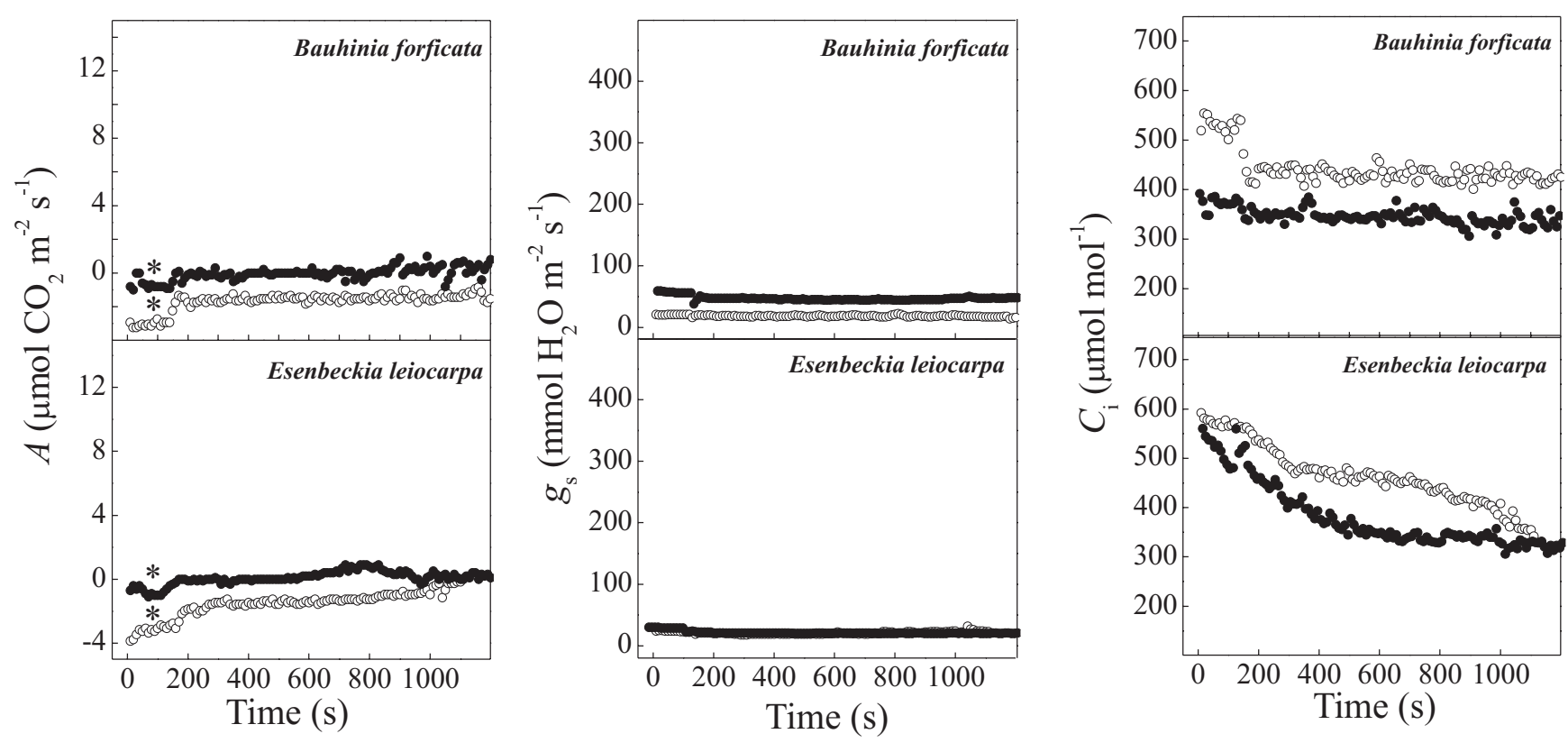

Figure 4. Time course of the net $\mathrm{CO}_{2}$ assimilation rate $(A)$ stomatal conductance $\left(g_{\mathrm{s}}\right)$ and intercellular $\mathrm{CO}_{2}$ concentration $\left(C_{\mathrm{i}}\right)$ in leaves of Bauhinia forficata and Esenbeckia leiocarpa in the understorey (closed symbols) and in the forest gap (open symbols) in August. Asterisks indicate the saturating light pulse after 10 min the darkness.

sun leaves.

In the understorey, E. leiocarpa presented a greater potential for sunfleck utilization than B. forficata, since it responded faster to increases in irradiance. In fact, some studies of lightfleck utilization have suggested that shade leaves may be capable of using sunflecks more 


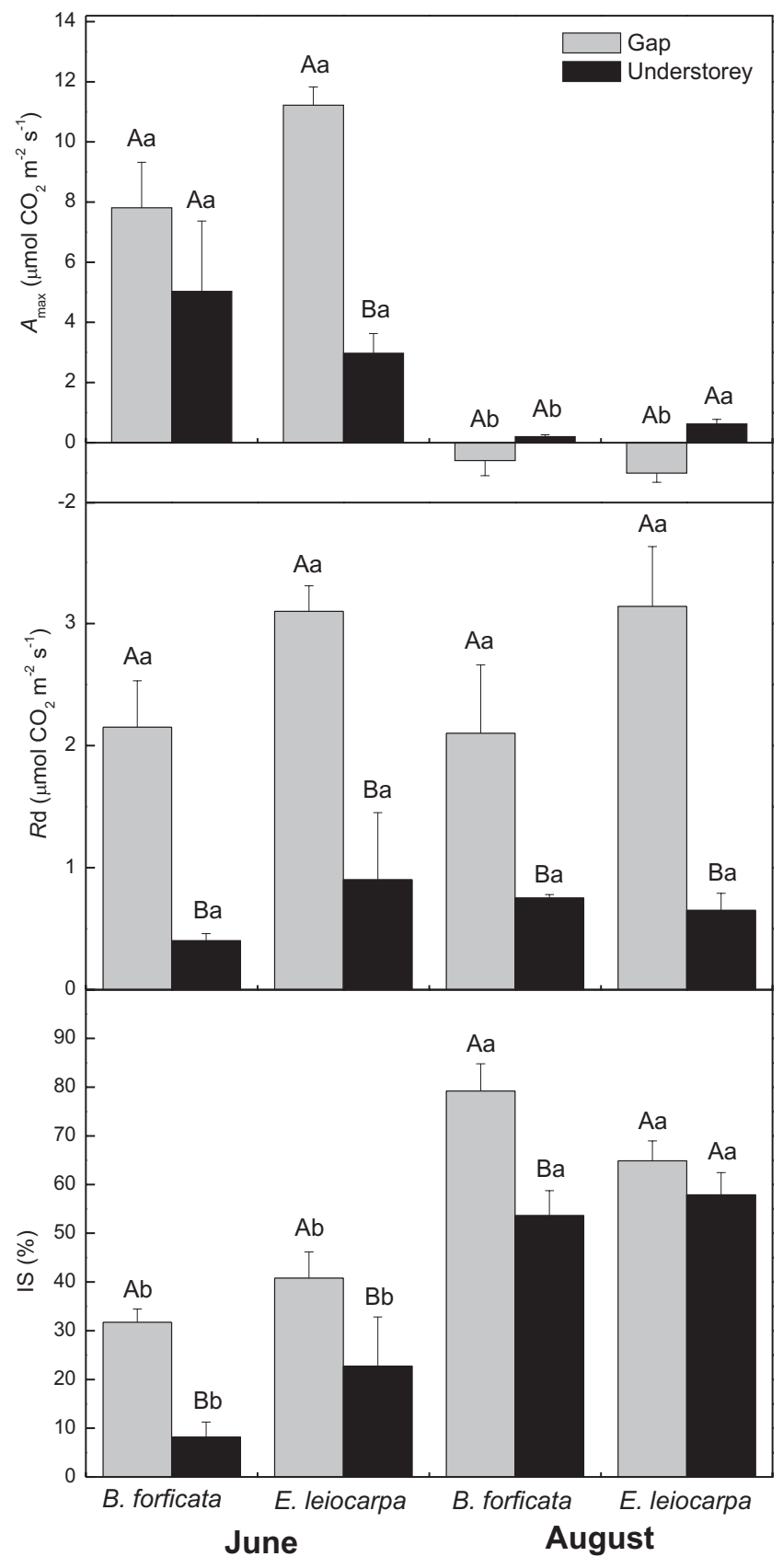

Figure 5. Maximum net $\mathrm{CO}_{2}$ assimilation rate $\left(A_{\text {max }}\right)$, dark respiration $\left(R_{\mathrm{d}}\right)$ and photosynthetic induction (IS) in leaves of Bauhinia forficata and Esenbeckia leiocarpa submitted to 10 min of darkness in both forest gap and understorey, in June and August 2006. Capital letters represent differences between environments whereas small letters represent mean statistical differences between months $(P<0.05$, Tukey's test $)$. Data are the mean $(n=3) \pm \mathrm{SE}$. efficiently than sun leaves (Chazdon and Pearcy, 1986b; Küppers and Schneider, 1993; Tang et al., 1994). This capacity could be related to a significant efficiency in increasing photosynthetic capacity exhibited by shade species in response to increasing light availability (Chow et al., 1988; Turnbull, 1991; Thompson et al., 1992). Valladares et al. (1997) demonstrated that understorey species showed the rapid induction, since IS was significantly higher, and higher lightfleck-use efficiency for short lightflecks compared to species found in clearings or small gaps.

Simulation studies indicated that under natural sunfleck regimes induction might reduce daily carbon gain of Alocasia macrorrhiza in the understorey by up to $25 \%$ over the expected if there was no induction requirement (Pearcy et al., 1994). Kirshbaum and Pearcy (1988) verified that in environments with fluctuating PPFD, the fast-inducing component is an important factor in determining the leaf potential for photosynthetic carbon gain in A. macrorrhiza. Induction appeared to be less limiting for sunfleck use in the understorey shrub Piper aequale than in the pioneer species $P$. auritum when both were grown in the shade (Tinoco-Ojanguren and Pearcy, 1992).

Chen and Klinka (1997) obtained similar results to the present study in Pseudotsuga menziesii, considered a late successional species, which showed a higher increase in photosynthetic rates in open-grown than understorey grown branches, after an increase in PPFD from 50 to $500 \mu \mathrm{mol} \mathrm{m} \mathrm{m}^{-2} \mathrm{~s}^{-1}$. However, those authors did not verify any difference in $R_{\mathrm{d}}$ between understorey and open-grown branches. Han et al. (1999) observed that in Fagus crenata, Daphniphylum humile and Acer rufinerve seedlings, both $R_{\mathrm{d}}$ and $A_{\max }$ were higher in the gap than in the understorey. Rijkers et al. (2000) studied photosynthetic induction in saplings of three shadetolerant tree species, comparing understorey and gap habitats. Their results showed that $A_{\max }$ in Dicorynia guianensis was similar between forest environments whereas for the other two species, Pourouma bicolor spp digitata and Vouacapoua americana, it was two-fold higher in the gaps than in the understorey.

Several authors also showed that $R_{\mathrm{d}}$ is greater in forest gap than in understorey environments (e.g., Ramos and Grace, 1990; Fredeen and Field, 1991). In this study, water deficit caused any increase in $R_{\mathrm{d}}$, however $R_{\mathrm{d}}$ may also be affected by plant developmental stage, 
temperature, nitrogen content (Amthor 2000; Lee et al., 2005), and seasonal environmental changes (Lee et al., 2005; Miranda et al., 2005). Some studies describe that pioneer species usually show higher leaf respiration than late successional ones (Bazzaz and Pickett 1980; Chazdon et al., 1996), but in the present report, significant differences in $R_{\mathrm{d}}$ between both species were generally not observed (Figure 5).

Combined shade and drought imposes special constraints, because mechanisms for capture of aboveground resources such as increased investment in leaf area restrict investment for the capture of below-ground resources (Sack et al., 2003). Probably the only way to avoid this conflict is to develop a reduced resource demand, which is characteristic of the stress-tolerator syndrome (Grubb, 1998). A decrease in $R_{\mathrm{d}}$ might be a mechanism that reduces this demand for resources.

The potential utilization of increases in irradiance was reduced under water-deficit conditions, since there was no substantial increase in $A_{\max }$. After saturating light pulse, $A$ increased slightly but did not exceed the light compensation point in both species in the forest gap. Accordingly, $R_{\mathrm{d}}$ was higher for both species in this environment, which presented a lower $\psi_{\mathrm{w}}$. In the understorey, the saturating light pulse allowed both species to reach the compensation point. Moreover, the reduction in $R_{\mathrm{d}}$ in the understorey could contribute to carbon economy. To maintain a positive carbon balance, assimilation rates must exceed respiration rates. Since $R_{\mathrm{d}}$ for both species was higher in the forest gap, plant susceptibility to water deficit effects in this environment could be higher.

As drought develops mesophyll metabolism may be impaired (Lawlor, 2002; Cornic and Fresneau, 2002), e.g. through decreasing both the activation and the carboxylase activity of Rubisco (Medrano et al., 2002; Parry et al., 2002). Moreover, lower Rubisco efficiency may be caused by an increased mesophyll resistance due to stomatal closure, constraining $\mathrm{CO}_{2}$ uptake into chloroplasts and increasing the oxygenase action of Rubisco, thus ultimately increasing photorespiration. Considering that RuBP regeneration, Rubisco activation and stomatal opening are limiting in different phases of photosynthetic induction, drought-stressed plants show low photosynthetic induction due possibly to the involvement of these factors in the induction process.
Strauss-Debenedetti and Bazzaz (1996) state that differences in photosynthetic characteristics are generally viewed as being adaptative in nature, although they may instead simply reflect the constraints imposed by resource limitation. As plasticity addresses the expression of variable phenotypes under different environments (Bradshaw, 1965), since both lightdemanding and shade-tolerant species are capable of phenotypic plasticity, it is possible to conclude that adjustments are not necessarily related to the successional status of species (Turnbull, 1991; Popma et al., 1992).

Considering the initial hypothesis, our results showed that there were no significant differences in photosynthetic induction between species in the same environment. Under water deficit both species presented limitation in $A_{\max }$, and steady-state $\mathrm{CO}_{2}$ assimilation (Figure 4) just remains around the compensation point in the understorey (Figure 5). Moreover, the hypothesis that late successional species under water deficit could maintain a state of photosynthetic induction higher than pioneers, which often show higher transpiration rates, was not supported since there was no significant differences between species.

Besides the restricted number of species representing different functional groups, which does not allow an ecophysiological generalization about ecological groups, we conclude that the physiological responses between species did not differ under normal and water-deficit conditions. Thus, growth environments rather than successional status promoted differences in photosynthetic light utilization. Noteworthy, the gap where the experiments were carried out is a small one, with canopy openness near $10 \%$. According to Chazdon et al. (1996), differences between pioneer and secondary species tend to be lower under small-gap conditions. Thus, it is likely that late successional species would have attained a suitable acclimation state in the small gap considered herein.

Although light has unquestionable importance to tropical forest development, this study showed that water deficit affected significantly the photosynthetic light utilization and consequently $\mathrm{CO}_{2}$ assimilation. Water deficit was a strong constraining resource on $A_{\max }$, mainly in the forest gap. Even though the IS tended to be higher in August, $A_{\max }$ was low and very close to the compensation point. The constraints in $A_{\max }$ were less 
pronounced in the understorey where plants at least reached the compensation point, while carbon gain by photosynthesis of the plants grown in the gap did not compensate the carbon loss by respiration (Figure 4). The fact that the plants had been near to the compensation point in the understorey indicated that, despite of low $A$, they reduced the reserve consumption by respiration. Ecologically, this carbon economy could improve plant survival under adverse environmental conditions, such as low-water availability.

Acknowledgments: This study was supported by the Fundação de Amparo à Pesquisa do Estado de São Paulo (FAPESP). M.T. Portes is grateful to the Coordenação de Aperfeiçoamento de Pessoal de Nível Superior (CAPES) for fellowships granted. The authors thank Daniel Santa Cruz Damineli for the critical review of the manuscript.

\section{REFERENCES}

Abrams MD, Mostoller AS (1995) Gas exchange, leaf structure and nitrogen in contrasting successional tree species growing in open and understorey sites during a drought. Tree Physiol. 15:361-370.

Amthor JS (2000) The McCree-de Wit-Penning de VriesThornley respiration paradigms: 30 years later. Ann. Bot. 86:1-20.

Bazzaz FA, Pickett STA (1980) Physiological ecology of tropical succession: A comparative review. Annu. Rev. Ecol. Syst. 11:287-310.

Björkman O (1981) Responses to different quantum flux densities, In: Lange OL, Noble PS, Osmond CB, Zeiger H, (eds), Encyclopedia of Plant Physiology, pp.57-102. Springer, Berlin.

Blum A (1997) Crop responses to drought and the interpretation of adaptation. In: Belhassen I (ed), Drought Tolerance in Higher Plants: Genetical, Physiological, and Molecular Biological Analysis, pp.57-70. Kluwer Academic Publishers, Dordrecht, The Netherlands.

Bradshaw AD (1965) Evolutionary significance of phenotypic plasticity in plants. Adv. Genet. 13:115-155.

Chaves MM (1991) Effects of water deficits on carbon assimilation. J. Exp. Bot. 42:1-16.

Chaves MM, Pereira JS, Maroco J, Rodrigues ML, Ricardo CPP, Osório ML, Carvalho I, Faria T, Pinheiro C (2002) How plants cope with stress in the field: photosynthesis and growth. Ann. Bot. 89:7-16.

Chazdon RL (1988) Sunflecks and their importance to forest understorey plants. Adv. Ecol. Res. 18:1-63.

Chazdon RL, Pearcy RW (1986a) Photosynthetic responses to light variation in rainforest species. I. Induction under constant and fluctuating light conditions. Oecologia 69:517-523.
Chazdon RL, Pearcy RW (1986b) Photosynthetic responses to light variation in rainforest species. II. Carbon gain and photosynthetic efficiency during lightflecks. Oecologia 69:524-531.

Chazdon RL, Pearcy RW, Lee DW, Fetcher N (1996) Photosynthetic responses of tropical forest plants to contrasting light environments. In: Mulkey SS, Chazdon RL, Smith AP (eds), Tropical Forest Plant Ecophysiology, pp.5-55. Chapman \& Hall, New York.

Chen HYH, Klinka K (1997) Light availability and photosynthesis of Pseudotsuga menziesii seedlings grown in the open and in the forest understorey. Tree Physiol. 17:23-39.

Chow WS, Qian L, Goodchild DJ, Anderson JM (1988) Photosynthetic acclimation of Alocasia macrorrhiza (L.) G. Don to growth irradiance: structure, function and composition of chloroplasts. Aust. J. Plant Physiol. 15:107-122.

Cornic G, Fresneau C (2002) Photosynthetic carbon reduction and carbon oxidation cycles are the main electron sinks for photosystem II activity during a mild drought. Ann. Bot. 89:887-894.

Denslow JS (1980) Gap partitioning among tropical rain forest trees. Biotropica 12:47-55.

Denslow JS (1987) Tropical rainforest gaps and tree species diversity. Annu. Rev. Ecol. Syst. 18:431-451.

Edwards G, Walker D (1983) $\mathrm{C}_{3}, \mathrm{C}_{4}$ : Mechanisms and Cellular and Environmental Regulation of Photosynthesis. University of California Press, Berkeley.

Embrapa (2003) Embrapa. Empresa Brasileira de Pesquisa Agropecuária - Banco de Dados Climáticos do Brasil. Available in <www.bdclima.cnpm.embrapa.br $>$. Accessed in: Jan 2007.

Fredeen AL, Field CB (1991) Leaf respiration in Piper species native to a Mexican rainforest. Physiol. Plant. 82:85-92.

Givnish TJ (1988) Adaptation to sun and shade: a wholeplant perspective. Aust. J. Plant Physiol. 15:63-92.

Grubb PJ (1998) A reassessment of the strategies of plants which cope with shortages of resources. Perspect. Plant Ecol. Evol. Syst. 1:3-31.

Han Q, Yamaguchi E, Odaka N, Kakubari Y (1999) Photosynthetic induction responses to variable light under field conditions in three species grown in the gap and understorey of a Fagus crenata forest. Tree Physiol. 19:625-634.

Kaiser WM (1987) Effects of water deficit on photosynthetic capacity. Physiol. Plant. 71:142-149.

Kirschbaum MUF, Pearcy RW (1988) Gas exchange analysis of the fast phase of photosynthetic induction in Alocasia macrorrhiza. Plant Physiol. 87:818-821.

Kuppers M, Schneider H (1993) Leaf gas exchange of beech (Fagus sylvatica L.) seedlings in lightflecks: effects of 
fleck length and leaf temperature in leaves grown in deep and partial shade. Trees 7:160-168.

Larcher W (1995) Physiological Plant Ecology. $3^{\text {rd }}$ Edition. Springer, Berlin.

Lawlor DW (2002) Limitation to photosynthesis in waterstressed leaves: stomata $v s$. metabolism and the role of ATP. Ann. Bot. 89:871-885.

Lee TD, Reich PB, Bolstad PV (2005) Acclimation to leaf respiration to temperature is rapid and related to specific leaf area, soluble sugars and leaf nitrogen across three temperate deciduous tree species. Funct. Ecol. 19:640-647.

Lorenzi H (1992) Árvores brasileiras: manual de identificação e cultivo de plantas arbóreas nativas do Brasil. Plantarum, Nova Odessa, São Paulo.

Malavolta E, Vitti GC, Oliveira S (1997) Avaliação do estado nutricional das plantas: princípios e aplicações. $2^{\text {nd }}$ ed. Potafos, Piracicaba.

Martins SV, Rodrigues RR (2002) Gap-phase regeneration in a semideciduous mesophytic forest, south-eastern Brazil. Plant Ecol. 163:51-62.

Medrano H, Escalona JM, Bota J, Gulías J, Flexas J (2002) Regulation of photosynthesis of $\mathrm{C} 3$ plants in response to progressive drought: stomatal conductance as a reference parameter. Ann. Bot. 89:895-905.

Miranda EJ, Vourlitis GL, Priante-Filho N, Priante PC, Campelo Jr JH, Suli GS, Fritzen CL, Lobo FA, Shiraiwa S (2005) Seasonal variation in the leaf gas exchange of tropical forest trees in the rain-savanna transition of the southern Amazon basin. J. Trop. Ecol. 21:451-460.

Parry MAJ, Andralojc PJ, Khan S, Lea PJ, Keys AJ (2002) Rubisco activity: effects of drought stress. Ann. Bot. 89:833-839.

Pearcy RW (1983) The light environment and growth of $\mathrm{C}_{3}$ and $\mathrm{C}_{4}$ tree species in the understorey of a Hawaiian forest. Oecologia 58:19-25.

Pearcy RW (1990) Sunflecks and photosynthesis in plant canopies. Annu. Rev. Plant Physiol. Plant Mol. Biol. 41:421-453.

Pearcy RW (1999) Responses of plants to heterogeneous light environments. In: Pugnaire FI, Valladares F (eds), Handbook of Functional Plant Ecology, pp.269-314. Marcel Dekker, New York.

Pearcy RW, Calkin H (1983) Carbon dioxide exchange of $\mathrm{C}_{3}$ and $\mathrm{C}_{4}$ tree species in the understorey of a Hawaiian forest. Oecologia 58:26-32.

Pearcy RW, Sims DA (1994) Photosynthetic acclimation to changing light environments: scaling from the leaf to the whole plant. In: Caldwell MM, Pearcy RW (eds), Exploitation of Environmental Heterogeneity by Plants: Ecophysiological Processes Above and Below Ground, pp.145-174. Academic Press, New York.
Pearcy RW, Chazdon RL, Gross LJ, Mott KA (1994) Photosynthetic utilization of sunflecks: a temporally patchy resource on a time scale of seconds to minutes. In: Caldwell MM, Pearcy RW (eds), Exploitation of Environmental Heterogeneity by Plants: Ecophysiology Processes Above and Below Ground, pp.175-208. Academic Press, New York.

Pfitsch WA, Pearcy RW (1989) Daily carbon gain by Adenocaulon bicolor a redwood forest understorey herb, in relation to its light environment. Oecologia 80:465-470.

Pickett STA, Collins SL, Arnesto JJ (1987) A hierarchical consideration of causes and mechanisms of succession. Vegetatio 69:109-114.

Pintado A, Valladares F, Sancho LG (1997) Exploring phenotypic plasticity in the lichen Ramalina capitata: morphology, water relations and chlorophyll content in north- and south-facing populations. Ann. Bot. 80: 345-353.

Popma J, Bongers F, Werger MJA (1992) Gap-dependence and leaf characteristics of trees in a tropical rain forest in Mexico. Oikos 63:207-214.

Ramos J, Grace J (1990) The effects of shade on the gas exchange of seedlings of four tropical trees from Mexico. Funct. Ecol. 4:667-677.

Riddoch I, Lehto T, Grace J. (1991) Photosynthesis of tropical tree seedlings in relation to light and nutrient supply. New Phytol. 119:137-147.

Rijkers T, de Vries PJ, Pons TL, Bongers F (2000) Photosynthetic induction in saplings of three shadetolerant tree species: comparing understorey and gap habitats in a French Guiana rain forest. Oecologia 125:331-340.

Sack L, Grubb PJ, Marañón T (2003) The functional morphology of juvenile plants tolerant of strong summer drought in shaded forest understories in southern Spain. Plant Ecol. 168:139-163.

Santos MG, Ribeiro RV, Oliveira RF, Machado EC, Pimentel C (2006) The role of inorganic phosphate on photosynthesis recovery of common bean after a mild drought deficit. Plant Sci. 170:659-664.

Santos MG, Ribeiro RV, Oliveira RF, Pimentel C (2004) Gas exchange and yield response to foliar phosphorus application in Phaseolus vulgaris L. under drought. Braz. J. Plant Physiol. 16:171-179.

Souza GM, Ribeiro RV, Santos MG, Ribeiro HL, Oliveira RF (2004) Functional groups of forest succession as dissipative structures: an applied study. Braz. J. Biol. 64:707-718.

Strauss-Debenedetti S, Bazzaz FA (1996) Photosynthetic characteristics of tropical trees along successional gradients. In: Mulkey SS, Chazdon RL, Smith AP (eds), 
Tropical Forest Plant Ecophysiology, pp.162-186. Chapman \& Hall, New York.

Sultan SE (1992) Phenotypic plasticity and the NeoDarwinian legacy. Evol. Trend Plant. 6:61-71.

Tang Y, Hiroshi K, Mitsumasa S, Izumi W (1994) Characteristics of transient photosynthesis in Quercus serrata seedlings grown under lightfleck and constant light regimes. Oecologia 100:463-469.

Tardieu F, Simonneau T (1998) Variability among species of stomatal control under fluctuating soil water status and evaporative demand: modelling isohydric and anisohydric behaviours. J. Exp. Bot. 49:419-432.

Thompson WA, Huang LK, Kriedemann PE (1992) Photosynthetic response to light and nutrients in suntolerant and shade-tolerant rainforest trees. II. Leaf gas exchange and component processes of photosynthesis. Aust. J. Plant Physiol. 19:19-42.

Tinoco-Ojanguren C, Pearcy RW (1992) Dynamic stomatal behavior and its role in carbon gain during lightflecks of a gap phase and an understorey Piper species acclimated to high and low light. Oecologia 92:222-228.

Turnbull MH (1991) The effect of light quantity and quality during development on the photosynthetic characteristics of six Australian rain-forest tree species. Oecologia 87:110-117.

Valladares F, Pearcy RW (2002) Drought can be more critical in the shade than in sun: a field study of carbon gain and photo-inhibition in a Californian shrub during a dry El Niño year. Plant Cell Environ. 25:749-759.

Valladares F, Allen MT, Pearcy RW (1997) Photosynthetic responses to dynamic light under field conditions in six tropical rainforest shrubs occurring along a light gradient. Oecologia 111:505-514.

Zipperlen SW, Press MC (1997) Photosynthetic induction and stomatal oscillations in relation to the light environment of two dipterocarp rain forest tree species. J. Ecol. 85:491-503. 